\title{
Vascular plants as surrogates of butterfly and grasshopper diversity on two Swiss subalpine summer pastures
}

\author{
Journal Article \\ Author(s): \\ Koch, Bärbel; Edwards, Peter J.; Blanckenhorn, Wolf U.; Buholzer, Serge; Walter, Thomas; Wuest, Rafael O.; Hofer, Gabriela \\ Publication date: \\ 2013-06
}

Permanent link:

https://doi.org/10.3929/ethz-b-000068314

Rights / license:

In Copyright - Non-Commercial Use Permitted

Originally published in:

Biodiversity and Conservation 22(6-7), https://doi.org/10.1007/s10531-013-0485-5 


\title{
Vascular plants as surrogates of butterfly and grasshopper diversity on two Swiss subalpine summer pastures
}

\author{
Bärbel Koch • Peter J. Edwards • Wolf U. Blanckenhorn • \\ Serge Buholzer • Thomas Walter • Rafael O. Wüest • Gabriela Hofer
}

Received: 20 November 2012/ Accepted: 9 April 2013/Published online: 18 April 2013

(C) Springer Science+Business Media Dordrecht 2013

\begin{abstract}
Summer pastures in the Swiss Alps are currently affected by land-use changes that cause a decrease in biodiversity. Although these habitats make up one-third of the whole Swiss agricultural area, direct payments dedicated to support their management are very low. Current political instruments do not support efforts to conserve the biodiversity in these areas, but a vegetation-based approach such as the one implemented in the permanently utilized agricultural areas is under discussion. However, available studies evaluating the surrogate value of vascular plants for other (particularly animal) taxa have yielded inconsistent results, and very few have been conducted in habitats at high elevations. We investigated the extent to which vascular plants are adequate surrogates for butterfly and grasshopper diversity, examining the congruence of species richness and community similarity in two heterogeneous subalpine pastures in the Swiss Alps. Results at the species richness level (Spearman's rank correlation) varied widely according to the study site and taxa assessed. In contrast, at the community similarity level (Procrustean randomization tests with Bray-Curtis similarity), congruencies between vascular plant and invertebrate taxa were generally highly significant. We therefore recommend the use of community similarity as a basis for estimating biodiversity patterns. Our results suggest that conservation measures aimed primarily at enhancing the floristic diversity of subalpine grasslands are also likely to benefit butterfly and grasshopper diversity, at least at the local scale.
\end{abstract}

B. Koch $(\bowtie) \cdot$ S. Buholzer $\cdot$ T. Walter $\cdot$ G. Hofer

Agroscope Reckenholz-Tänikon Research Station ART, Reckenholzstrasse 191, 8046 Zurich, Switzerland

e-mail: baerbel.koch@hotmail.com

B. Koch · P. J. Edwards

Institute of Integrative Biology, ETH Zurich, Universitätstrasse 16, 8092 Zurich, Switzerland

W. U. Blanckenhorn

Institute of Evolutionary Biology and Environmental Studies, University of Zurich,

Winterthurerstrasse 190, 8057 Zurich, Switzerland

R. O. Wüest

Swiss Federal Research Institute WSL, Zürcherstrasse 111, 8903 Birmensdorf, Switzerland 
Keywords Arthropods $\cdot$ Community similarity $\cdot$ Plants $\cdot$ Species richness $\cdot$ Summer pastures $\cdot$ Surrogate taxa

\section{Introduction}

Agricultural activities have shaped Swiss alpine landscapes over centuries, and contributed greatly to their biological diversity (Bätzing 2003). Despite their anthropogenic origin, the subalpine grasslands used as summer pastures have a very high conservation value, harbouring up to three times as many species as the forest they replaced (Zoller and Bischof 1980). However, changing social and economic conditions have affected land use in alpine regions, with subalpine pastures developing in diverging ways; whereas productive and accessible areas are now managed more intensively, remote, steep and less productive areas are underused or even abandoned. Both trends tend to cause a decrease in biodiversity (MacDonald et al. 2000; Tasser and Tappeiner 2002), and without measures to counteract them, the summer pastures in the forest belt will soon lose much of their conservation value (Mack et al. 2008).

To halt the decline of biodiversity in agricultural landscapes, many European countries including Switzerland have introduced agri-environmental schemes (Kleijn and Sutherland 2003). Since 1999, Swiss farmers have been eligible for direct payments provided they manage their permanently utilized agricultural area according to specified criteria (BLW 1998). One of these is that at least $7 \%$ of the agricultural land should be managed as ecological compensation areas (ECAs), which may include extensively managed meadows and pastures, and traditional orchards. Furthermore, an ordinance introduced in 2001 entitles farmers to receive result-oriented financial support for ECAs that meet certain standards of ecological quality (BLW 2001). In this context, ecological quality is defined by the presence in sufficient quantity of certain plant taxa considered to be of conservation value. However, alpine summer pastures are not supported by these instruments because they are not regarded as permanently used agricultural land (BLW 2007). Thus, although the pastures in the Swiss Alps and Jura Mountains make up one-third of the total Swiss agricultural area (Baur et al. 2007), they accounted for $<4 \%$ of direct agricultural payments in 2010 (BLW 2011). It is becoming increasingly clear that more financial support will be needed to ensure that these pastures continue to be used for grazing during the summer period (Mack and Flury 2008), and an extension of the national agri-environmental schemes to include the ecological quality of summer pasture areas is currently under discussion. Such a development would help protect the biodiversity of subalpine grasslands while supporting the livelihoods of farmers who use these areas (Klimek et al. 2008; Wittig et al. 2006).

The administration of such a scheme, however, would present practical difficulties because monitoring biodiversity in subalpine grasslands is no simple matter. As the whole of biodiversity cannot be recorded (McGeoch 1998; Noss 1990), surrogate indicators are widely used in conservation biology and planning (Caro and O'Doherty 1999; Favreau et al. 2006). Although this approach saves time and money, it depends upon a crucial assumption-that the indicator taxa can serve as a surrogate for a broader range of taxonomic diversity (Howard et al. 1998; Prendergast et al. 1993). Vascular plants are commonly used because they are relatively easy to sample and identify, react sensitively to environmental conditions, and support a large number of animal species (e.g. Marini et al. 2007; Niemelä and Baur 1998). The use of selected vascular plants for assessing ecological 
quality is the basis of the result-based approach in both Switzerland and Germany (Oppermann and Gujer 2003; Wittig et al. 2006). This approach has been shown to be both efficient and well accepted by farmers (Klimek et al. 2008), though studies investigating the surrogate value of plants in general, and subsets of plant species in particular, for other (primarily animal) taxa have produced results in support (Duelli and Obrist 1998; Nipperess et al. 2012; Panzer and Schwartz 1998; Pharo et al. 1999; Sauberer et al. 2004) and in contradiction (Billeter et al. 2008; Chiarucci et al. 2007, 2005; Niemelä and Baur 1998; Santi et al. 2010; Vessby et al. 2002). Furthermore, very few of these studies have considered the relationships between plant and invertebrate diversity in subalpine areas (Favreau et al. 2006).

The aim of this study was to investigate the adequacy of various measures of plant species richness and composition as surrogates for the diversity of diurnal butterflies and grasshoppers in the summer pasture habitat. We examined the small-scale congruencies of species richness and community similarity patterns in two highly heterogeneous subalpine pastures in the Swiss Alps.

\section{Methods}

Study sites and sampling design

The investigation was carried out on two subalpine pastures around the villages of Mesocco $\left(46^{\circ} 23^{\prime} 31^{\prime \prime} \mathrm{N} / 9^{\circ} 13^{\prime} 58^{\prime \prime} \mathrm{E}\right)$ and Guarda $\left(46^{\circ} 46^{\prime} 33^{\prime \prime} \mathrm{N} / 10^{\circ} 08^{\prime} 59^{\prime \prime} \mathrm{E}\right)$ in the Canton of Grisons in southeastern Switzerland (Fig. 1). The mean annual precipitation measured at weather stations close to the survey sites between 1961 and 1990 was 1,864 and $693 \mathrm{~mm}$ year $^{-1}$ for Mesocco and Guarda, respectively (Schweizerische Meteorologische Anstalt 2008). Crystalline underlying rocks dominate at both sites (Reinhard et al. 1962). Both pastures have a south-west aspect, are $\sim 1.5 \mathrm{~km}^{2}$ in area, grazed by cattle, and situated in marginal locations just above the present tree line (1,762-2,064 m elevation in Mesocco and 2,097-2,410 $\mathrm{m}$ in Guarda). The vegetation is composed of a mosaic of grasses and herbs, mainly Nardus stricta, and dwarf ericaceous shrubs and junipers (Juniperus spp.). Fifty-four plots of $30 \times 30 \mathrm{~m}\left(900 \mathrm{~m}^{2}\right)$ were located with a systematic sampling (regular grid with a $155 \mathrm{~m}$ resolution; see Fig. 1) on each pasture. Hazardous regions of the pasture had to be excluded from the survey resulting in a final sample of 49 plots at Mesocco and 50 plots at Guarda.

Plant, butterfly and grasshopper sampling

Data collection was carried out between June and September 2010. To account for the heterogeneity in the plots, plants were surveyed in nine quadrats of $1 \mathrm{~m}^{2}$ placed systematically within the $900 \mathrm{~m}^{2}$ plot (Fig. 1). The plant cover was estimated using the BraunBlanquet scale (Braun-Blanquet 1964) and the taxonomy follows Lauber and Wagner (2001). We also recorded the presence of any additional species absent from the nine quadrats by searching the whole plot for $30 \mathrm{~min}$. Two plant data sets were derived in this way: a "cover data set" from the nine $1 \mathrm{~m}^{2}$ quadrats consisting of abundances acquired from the Braun-Blanquet scale, and a "presence data set" of all species recorded in the $900 \mathrm{~m}^{2}$ plot. We recorded all adult butterflies (Rhopalocera, Hesperiidae and Zygaenidae) and grasshoppers (Ensifera and Caelifera) by walking over the $900 \mathrm{~m}^{2}$ plot in a serpentinelike transect with a net (see Balmer and Erhardt 2000; Fig. 1). Both taxa were identified 


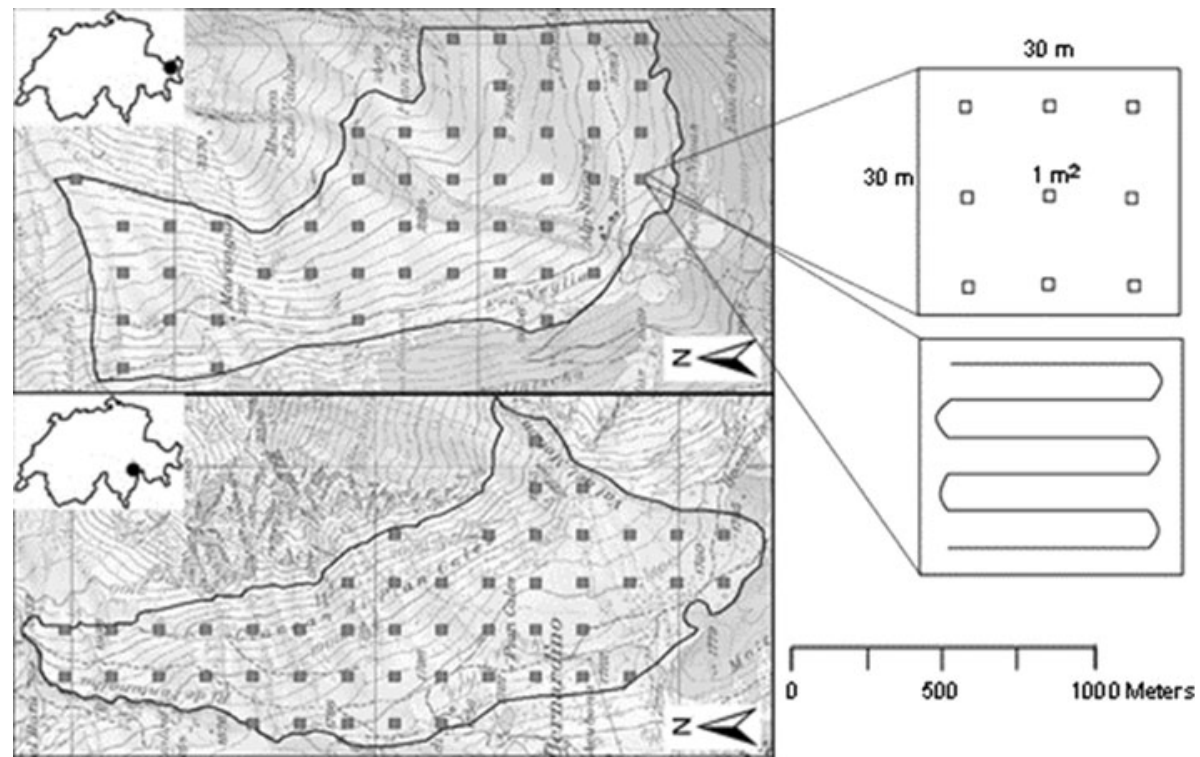

Fig. 1 On the left, the pasture areas in Guarda (top) and Mesocco (bottom) showing the boundary and the systematically located plots. The Topographic Map 1:25,000 (2012 (CSwisstopo) is shown in the background. On the right, the sampling design used for plants (top) and insects (bottom)

visually, and grasshoppers also acoustically, during sunny days with little or no wind between 10:00 and 17:00. The butterfly survey was performed on five occasions, and the grasshopper survey on two occasions. The higher survey effort for butterflies reflects the fact that some butterflies became active earlier than most grasshoppers, and the observation period was therefore longer (May-September for butterflies and July-September for grasshopers). Some butterflies (mostly individuals belonging to the Genera Erebia, Pyrgus, Adscita and Zygaena) were retained for accurate genital identification, but all other insects were released where they had been caught. Butterfly nomenclature followed BühlerCortesi (2009) and grasshopper nomenclature Baur et al. (2006). To consider the overall species diversity throughout the whole summer period, data of different sampling times were pooled at the plot level prior to data analysis for both insect taxa.

\section{Measures of species richness and quality}

Four plant measures were used to test congruence of the butterfly and grasshopper data at the species richness level: (1) total number of plant species, hereafter species richness, derived from the "presence data set"; (2) the number of plant target and characteristic species of nature conservation value considered to indicate ecological quality of Swiss agricultural surfaces (BAFU and BLW 2008), hereafter plant 'quality species'; (3) the average number of species within the nine $1 \mathrm{~m}^{2}$ quadrats ( $\alpha$ diversity), and (4) the number of species among quadrats ( $\beta$ diversity), derived by subtracting $\alpha$ diversity from the total number of species ( $\gamma$ diversity) in the nine quadrats (Formula 7 in Lande 1996). For the butterfly and grasshopper taxa two measures were used for comparison: (1) species richness (i.e. total number of species), and (2) the number of 'quality species' (i.e. number of target and characteristic species). 
Comparisons between the four plant measures and the two measures for butterflies and grasshoppers were made by means of pairwise Spearman's rank correlation tests as the data were not normally distributed and this measure only assumes monotonic instead of linear relationships. Because only one grasshopper quality species, Gomphocerus sibiricus, was recorded at Mesocco, comparisons using the number of grasshopper quality species were not performed for this site. Spatial autocorrelation in the data was examined using a Mantel test with 10,000 permutations. Only species data in Guarda were found to be spatially autocorrelated, so for statistical inference partial Spearman's rank correlations between the variables controlling for the effect of geographical variables were determined in all cases (Dale and Fortin 2009). Analyses were performed using the "ppcor" (Kim 2011) and "vegan" (Oksanen et al. 2012) packages of the statistical program R (R Core Team 2012). We did not apply sequential Bonferroni corrections for correlations in agreement with the objections of Moran (2003) and similar studies dealing with surrogate indicators (Fattorini 2010; Mandelik et al. 2012).

\section{Community similarity}

We used procrustean randomization tests (PROTEST; Jackson 1995) for pairwise community similarity comparisons between the plant and insect taxa at each site. This approach was preferred to the commonly used Mantel test because of its greater power in detecting congruence between two community matrices (Gioria et al. 2011; Peres-Neto and Jackson 2001). PROTEST attempts to minimize the sum-of-squared deviations between two data matrices by stretching and rotating the points in one matrix, while still maintaining the relative distance between points within each matrix (Jackson 1995). Both the cover and presence plant data sets were used for comparisons with the insect abundance data. Cover data of plants and abundance data for insects were square roottransformed prior to data analysis to improve normality. Bray-Curtis similarity matrices for the species data were then calculated using the transformed cover/abundance data as well as presence data. Because a Mantel test (10,000 permutations) between species assemblages (Bray-Curtis similarity) and the geographic distance matrix revealed spatial autocorrelation in the community data of both the Mesocco and Guarda sites, a partial PROTEST following the approach of Peres-Neto and Jackson (2001) was performed. This method permits the degree of association of two matrices to be calculated using PROTEST while fixing the potential effect of geographical variables. The matrices were standardized using non-metric multidimensional scaling (NMDS), and information on the stress value was used to define the number of axes to use. Four NMDS axes were retained for both the species and geographical matrices. Two steps were used to perform partial PROTEST (Peres-Neto and Jackson 2001): First, for each axis retained from species NMDS analysis, multiple regressions with all geographical axes were performed. Then the residuals obtained from these multiple regressions were used to carry out pairwise partial PROTEST analysis. The Procrustes correlations $r=\sqrt{1-m}$ were derived from the symmetric Procrustes residuals $(m)$, which are the sum-of-square residuals between matrices in their optimal superimposition. Because of too many zero values in the matrix of butterfly and grasshopper quality species, it was not possible to carry out a reasonable NMDS and thus PROTEST analysis. Analyses were performed using the "vegan" package (Oksanen et al. 2012) in R (R Core Team 2012). 


\section{Results}

In Mesocco 318 plant, 44 butterfly and 8 grasshopper species were recorded and identified. In Guarda 332 plant, 52 butterfly and 14 grasshopper species were recorded. More exhaustive species and abundance data for the three taxa are summarized in Table 1. In general, plant, butterfly and grasshopper species richness and abundance at the two sites were similar.

Measures of species richness and quality

The various measures of plant diversity-species richness, number of 'quality' species, $\alpha$ and $\beta$ diversity-generally showed moderate to strong positive correlations with both the butterfly total species and quality species richness at both study sites (Table 2; Fig. 2). At Mesocco, however, the correlations between the $\alpha$ diversity of plants and both total and quality species richness of butterflies did not quite reach the level for significance ( $p=0.064$ and $p=0.113$ ). At Guarda, the correlations between the four plant measures and species richness of grasshoppers were not significant (Table 2; Fig. 3).

\section{Community similarity}

Cover as well as presence community data of vascular plants coincided well with insect abundance at both sites. Apart from the insignificant relationships between plant species cover and grasshopper abundance as well as plant quality species cover and butterfly and grasshopper abundance at Mesocco, all relationships between plant and insect community data showed highly significant positive correlations at both sites (Table 3; Figs. 4, 5).

\section{Discussion}

In this study of two subalpine pastures, we found generally strong and positive congruence between various measures of plant diversity (species richness patterns, $\alpha$ diversity and $\beta$ diversity) and the species richness of butterflies and grasshoppers, though with some differences between the insect taxa and the sites assessed. However, congruencies between plant and invertebrate communities were consistently strong for both taxa and sites regarded.

One explanation for the congruence between plants and butterflies is their producerconsumer relationship. Most butterflies are dependent upon one or a few plant species during their larval stage, while adult butterflies also show more or less strong associations with certain flowering plants for nectar (e.g. Tudor et al. 2004). These relationships are well reflected in our results obtained, which agree with previous studies and confirm that vascular plants can be taken as a good surrogate for butterflies both at the levels of species richness (Panzer and Schwartz 1998; Pearman and Weber 2007) and community similarity (Santi et al. 2010; Su et al. 2004).

The results for grasshoppers are less clear. A significant positive correlation between vascular plants and grasshoppers was found in a study of low altitude agricultural landscapes in Austria (Sauberer et al. 2004). However, our data only partially support their findings, with differences between the two study areas, particularly at the level of species richness. Although grasshoppers also depend upon vascular plants, most species are 


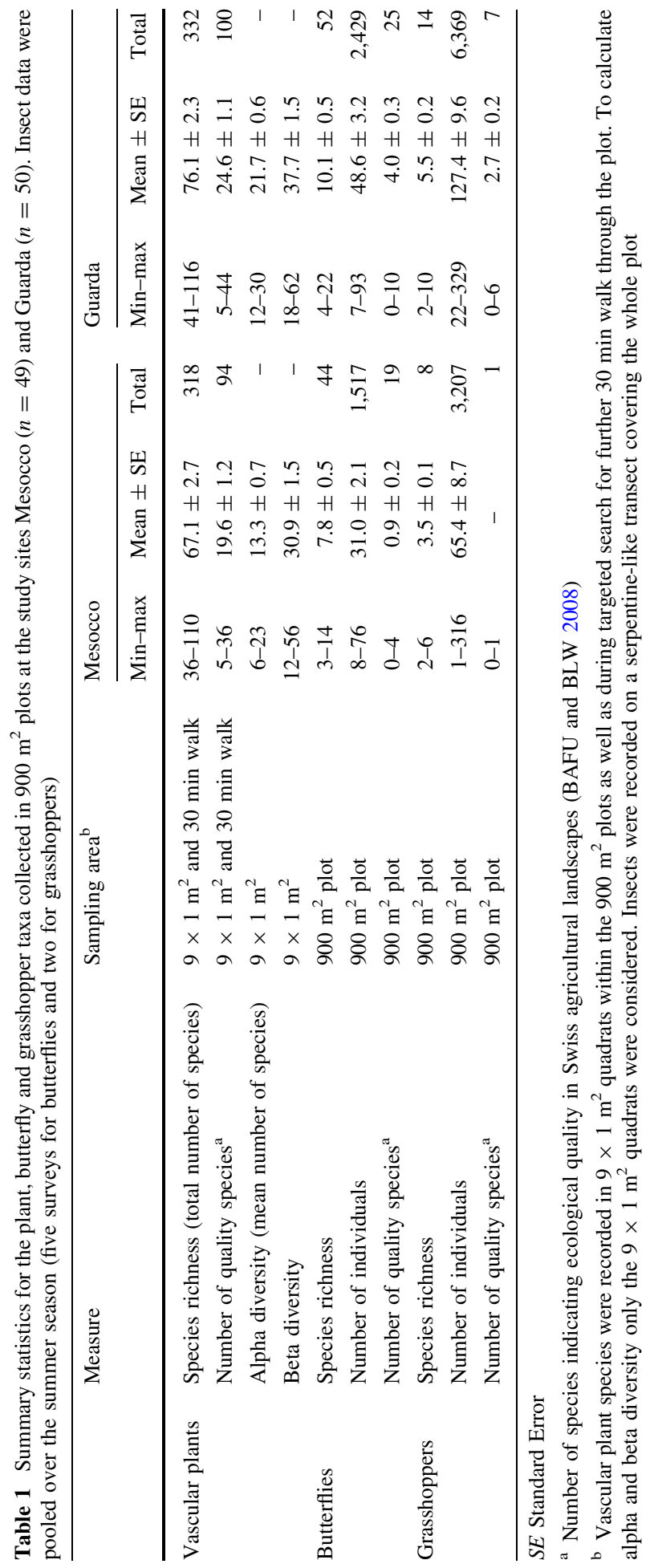


Table 2 Pairwise comparisons between four plant measures and two measures for butterflies and grasshoppers in the study sites Mesocco $(n=49)$ and Guarda $(n=50)$. Partial Spearman's rank correlation and significance values ( $p$, in brackets; significant values in bold) are reported

\begin{tabular}{|c|c|c|c|c|c|}
\hline \multirow{3}{*}{$\begin{array}{l}\text { Study } \\
\text { areas }\end{array}$} & \multirow{3}{*}{$\begin{array}{l}\text { Comparisons } \\
\text { Sampling area }\end{array}$} & \multicolumn{4}{|l|}{ Plant measures } \\
\hline & & $\begin{array}{l}\text { Species } \\
\text { richness }\end{array}$ & $\begin{array}{l}\text { Quality } \\
\text { species }\end{array}$ & $\alpha$-Diversity & $\beta$-Diversity \\
\hline & & $900 \mathrm{~m}^{2}$ & $900 \mathrm{~m}^{2}$ & $9 \times 1 \mathrm{~m}^{2}$ & $9 \times 1 \mathrm{~m}^{2}$ \\
\hline \multirow[t]{4}{*}{ Mesocco } & Butterfly species richness & $0.362(0.009)$ & $0.337(0.016)$ & $0.266(0.064)$ & $0.396(0.004)$ \\
\hline & Butterfly quality species & $0.302(0.034)$ & $0.273(0.057)$ & $0.230(0.113)$ & $0.353(0.011)$ \\
\hline & $\begin{array}{l}\text { Grasshopper species } \\
\text { richness }\end{array}$ & $0.387(0.005)$ & $0.408(0.003)$ & $\begin{array}{l}0.492 \\
\quad(<0.001)\end{array}$ & $0.375(0.007)$ \\
\hline & $\begin{array}{l}\text { Grasshopper quality } \\
\text { species }^{\text {a }}\end{array}$ & - & - & - & - \\
\hline \multirow[t]{4}{*}{ Guarda } & Butterfly species richness & $0.579(<0.001)$ & $\begin{array}{l}0.668 \\
(<0.001)\end{array}$ & $\begin{array}{l}0.551 \\
(<0.001)\end{array}$ & $\begin{array}{l}0.550 \\
\quad(<0.001)\end{array}$ \\
\hline & Butterfly quality species & $0.426(0.001)$ & $\begin{array}{l}0.472 \\
\quad(<0.001)\end{array}$ & $\begin{array}{l}0.460 \\
\quad(<0.001)\end{array}$ & $0.404(0.003)$ \\
\hline & $\begin{array}{l}\text { Grasshopper species } \\
\text { richness }\end{array}$ & $0.245(0.087)$ & $0.164(0.259)$ & $0.139(0.343)$ & $0.270(0.057)$ \\
\hline & $\begin{array}{l}\text { Grasshopper quality } \\
\text { species }\end{array}$ & $0.227(0.114)$ & $0.148(0.309)$ & $0.052(0.722)$ & $0.224(0.120)$ \\
\hline
\end{tabular}

a This comparison was not made because of the presence of only one quality grasshopper species at the Mesocco site
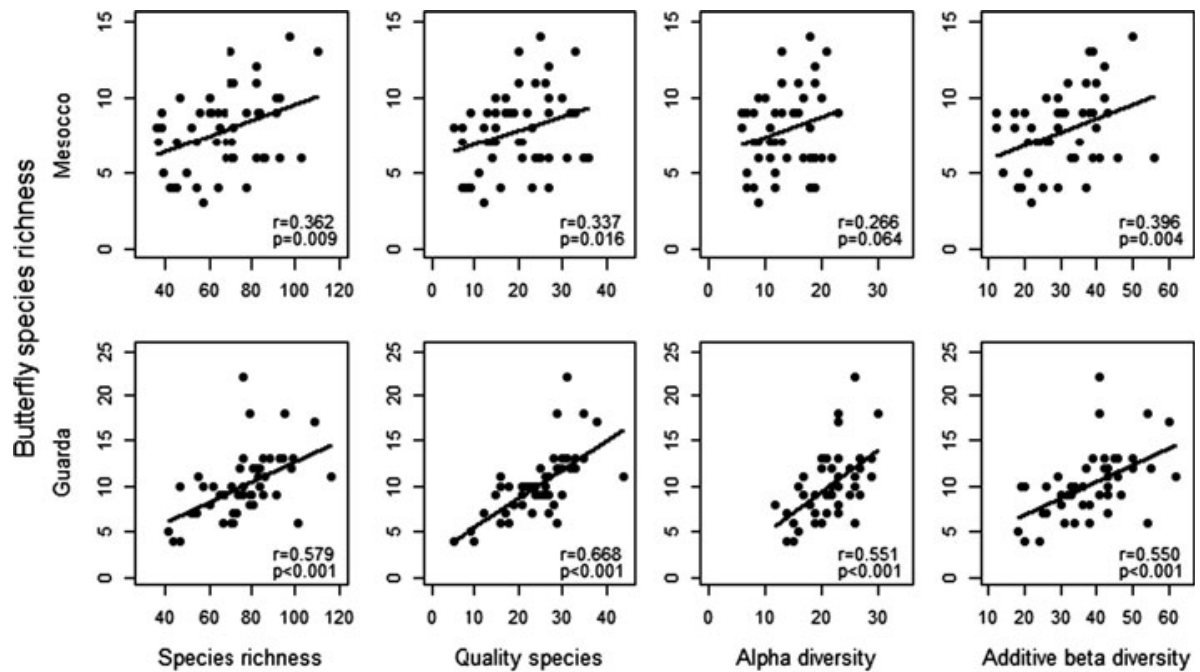

Vascular plant measures

Fig. 2 Four plant measures against butterfly species richness in Mesocco $(n=49)$ and Guarda $(n=50)$. Spearman's rank correlations (r) and significances $(p)$ are reported in the single graphs. Regression lines are shown to simplify interpretation

generalists and their diets may include a relatively wide range of plant species. Thus, aspects such as biomass production, vegetation structure or microclimate are more important in shaping grasshopper distribution than plant species richness per se (Detzel 


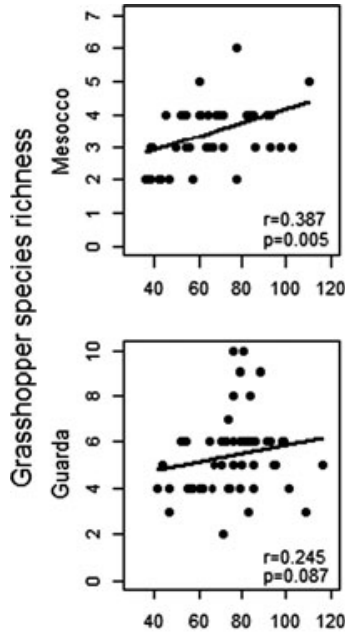

Species richness
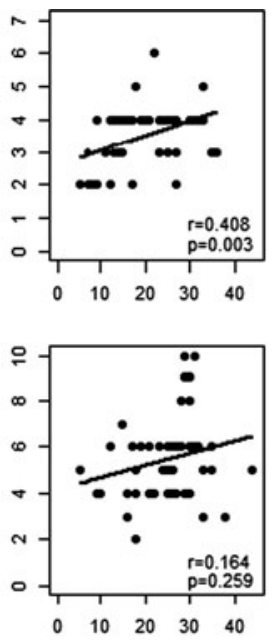

Quality species
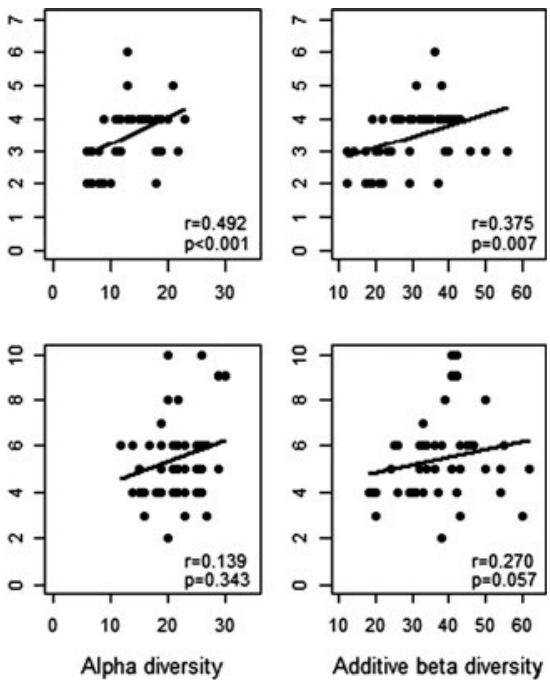

Additive beta diversity

Vascular plant measures

Fig. 3 Four plant measures against grasshopper species richness in Mesocco $(n=49)$ and Guarda $(n=50)$. Spearman's rank correlations $(r)$ and significances $(p)$ are reported in the single graphs. Regression lines are shown to simplify interpretation

Table 3 Correlation and significance values ( $p$, in brackets; significant values in bold) of partial PROTEST with 1,000 permutations between (Bray-Curtis) community similarity matrices among vascular plants, butterflies and grasshoppers in Mesocco $(n=49)$ and Guarda $(n=50)$. Cover data for plants and abundance data for insects were square-root transformed prior to analysis

\begin{tabular}{|c|c|c|c|c|c|}
\hline \multirow{2}{*}{$\begin{array}{l}\text { Study } \\
\text { areas }\end{array}$} & \multirow{2}{*}{$\begin{array}{l}\text { Comparisons } \\
\text { Sampling area }\end{array}$} & \multicolumn{4}{|l|}{ Plant measures } \\
\hline & & $\begin{array}{l}\text { All species } \\
\text { cover } \\
9 \times 1 \mathrm{~m}^{2}\end{array}$ & $\begin{array}{l}\text { All species } \\
\text { presence } \\
900 \mathrm{~m}^{2}\end{array}$ & $\begin{array}{l}\text { Quality } \\
\text { species cover } \\
9 \times 1 \mathrm{~m}^{2}\end{array}$ & $\begin{array}{l}\text { Quality species } \\
\text { presence } \\
900 \mathrm{~m}^{2}\end{array}$ \\
\hline \multirow[t]{2}{*}{ Mesocco } & $\begin{array}{l}\text { Abundance of butterfly } \\
\text { species }\end{array}$ & $0.516(0.001)$ & $0.480(0.001)$ & $0.164(0.290)$ & $0.447(0.001)$ \\
\hline & $\begin{array}{l}\text { Abundance of } \\
\text { grasshopper species }\end{array}$ & $0.285(0.078)$ & $0.329(0.007)$ & $0.092(0.559)$ & $0.355(0.004)$ \\
\hline \multirow[t]{2}{*}{ Guarda } & $\begin{array}{l}\text { Abundance of butterfly } \\
\text { species }\end{array}$ & $0.593(0.001)$ & $0.577(0.001)$ & $0.576(0.001)$ & $0.537(0.001)$ \\
\hline & $\begin{array}{l}\text { Abundance of } \\
\text { grasshopper species }\end{array}$ & $0.712(0.001)$ & $0.649(0.001)$ & $0.607(0.001)$ & $0.584(0.001)$ \\
\hline
\end{tabular}

1998; Szövényi 2002). Furthermore, the number of grasshopper species surveyed at these higher altitudes was relatively low. Results for the species richness and their interpretation should therefore be treated with caution as the small species pool might have affected the statistical outcomes, at least in terms of reduced power to obtain significant results. Despite the few species, the total numbers of grasshoppers at both sites were high, making community similarity a more appropriate measure for comparison. Oertli et al. (2005) also found stronger correlations between grasshoppers and bees using community similarity data instead of species numbers. 

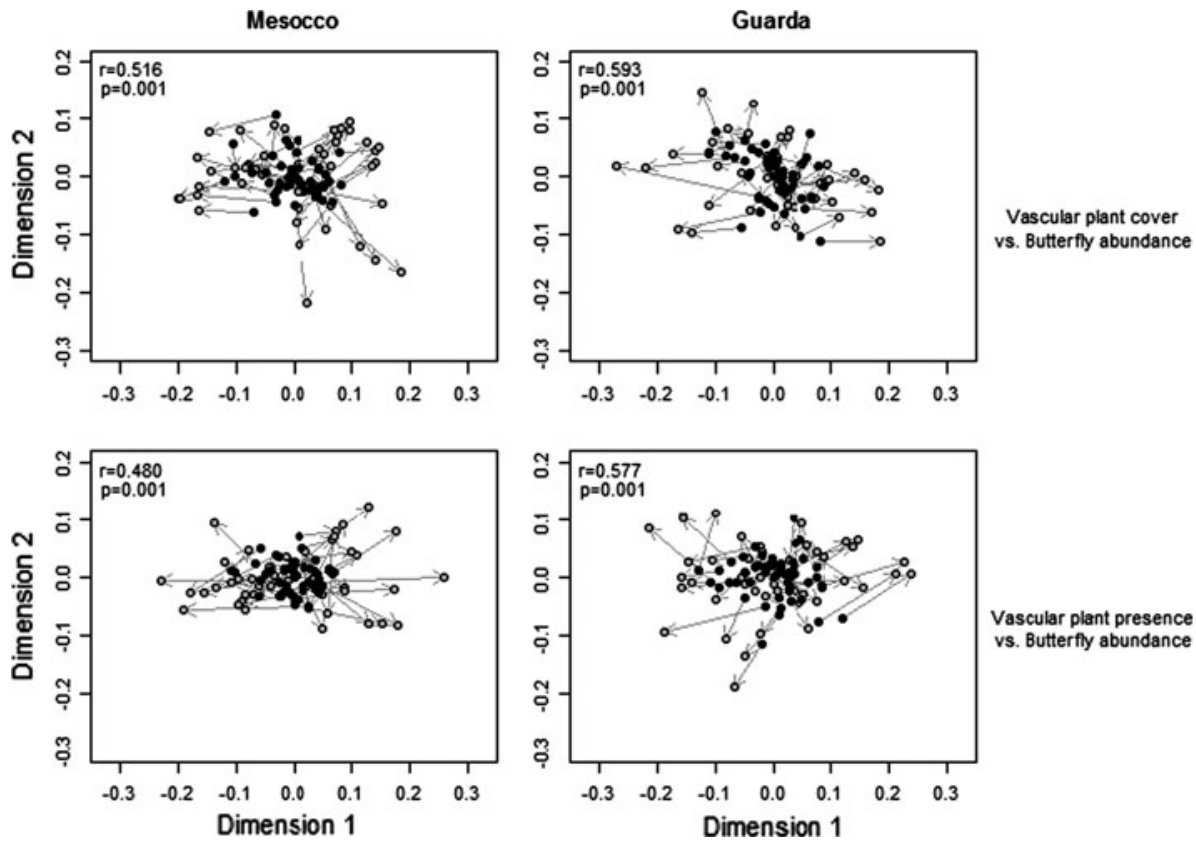

Vascular plant presence vs. Butterfly abundance

Fig. 4 Procrustean superimposition plots between vascular plant cover or presence and butterfly abundance in Mesocco $(n=49)$ and Guarda $(n=50)$. Procrustes correlations $(\mathrm{r})$ and significances $(\mathrm{p})$ are reported in the graphs. The procrustean errors are shown in the graphs as arrows, the length of which illustrates the amount of difference between the community similarities (Bray-Curtis similarity) of the vascular plant and butterfly taxa. The arrows start from the original rotated data (butterflies, black circles) and points to the target data (vascular plants, greycircles)

In general, insect communities showed higher similarity among plots than plant communities. Particularly the eight rather generalist grasshopper species at the Mesocco site caused the species assemblages to be very homogeneous among plots with rather different vegetation communities (Fig. 5). These findings are comparable to observations of Murdoch et al. (1972), who found the Homoptera assemblages in three old fields to be more similar than those of plants. This suggests less site specificity in the insect communities, which seem to be relatively unaffected by differences in the plant communities. One explanation might be the greater mobility of butterflies and grasshoppers, which leads to less distinct boundaries between communities (Samways et al. 2012), reinforcing the argument for a vegetation-based approach.

Besides the direct associations of vascular plants with butterflies and grasshoppers, the taxa also share similar responses to environmental factors and management (e.g. Marini et al. 2009). Oertli et al. (2005) suggested that congruence of diversity patterns is more likely at local scales when there is a strong environmental gradient to which the taxa respond similarly. For example, Su et al. (2004) concluded that the congruence of plant, bird and butterfly communities was due to a hydrological gradient. The sites in our study were topographically very heterogeneous with very variable micro-climatic conditions, which are likely to have influenced the distribution of species and thus potentially underlie congruencies.

The spatial scale at which species diversity is studied may also affect the congruence among taxa (Favreau et al. 2006; Wolters et al. 2006), whilst local environmental 

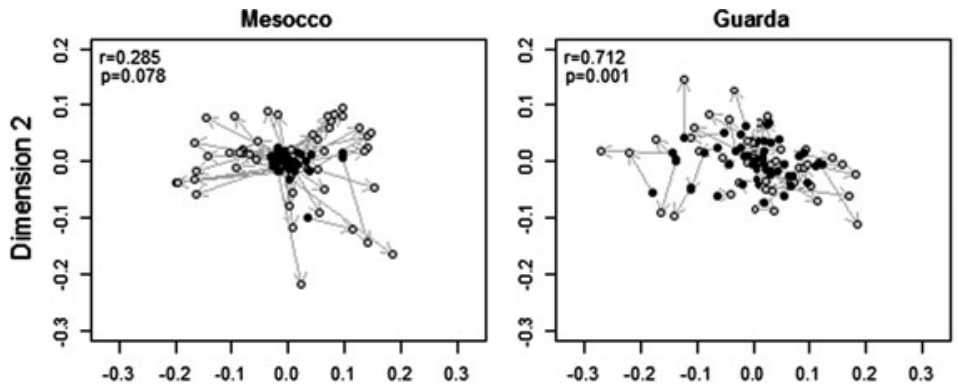

Vascular plant cover vs. Grasshopper abundance
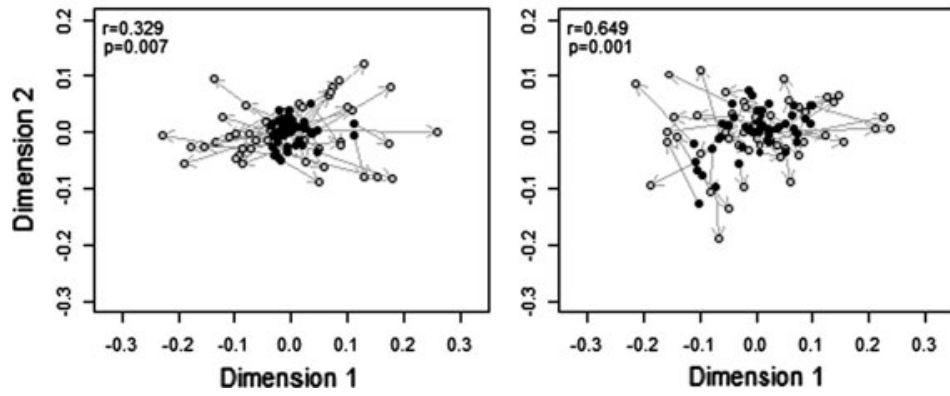

Vascular plant presence vs. Grasshopper abundance

Fig. 5 Procrustean superimposition plots between vascular plant cover or presence and grasshopper abundance in Mesocco $(n=49)$ and Guarda $(n=50)$. Procrustes correlations (r) and significances $(\mathrm{p})$ are reported in the graphs. The procrustean errors are shown in the graphs as arrows, the length of which illustrates the amount of difference between the community similarities (Bray-Curtis similarity) of the vascular plant and grasshopper taxa. The arrows start from the original rotated data (grasshoppers, black circles) and points to the target data (vascular plants, grey circles). It is worth to note the homogeneous grasshopper communities in Mesocco compared to Guarda

conditions are likely to be more important at the small scale, evolutionary, historical or climatic factors may be more influential at larger scales (Heino et al. 2009). Although it is reported that taxa show better correspondence in species richness at larger scales (Wolters et al. 2006), the importance of studying congruence among taxa at a small scale has been repeatedly emphasized (Vera et al. 2011; Weaver 1995). It can be argued that this is the scale at which conservation actions and management planning such as agri-environmental schemes are mostly carried out, and therefore the scale at which congruence analyses would be of most practical relevance. Even though ours was a small-scale study, vascular plants performed well as surrogates of butterflies and grasshoppers at the community similarity level. Despite divergent results of surrogate studies, vascular plants have been repeatedly recommended as one of the best indicators for overall biodiversity (Duelli and Obrist 1998; Kati et al. 2004; Sauberer et al. 2004).

In order to capture different aspects of species diversity patterns, we also used measures of plant diversity other than species richness. Whilst Spearman rank correlations between the average plant diversity and invertebrate taxa within samples ( $\alpha$ diversity) were lower, correlation values for the diversity among samples ( $\beta$ diversity) were as high as those for the species richness, and in some cases even higher. Not only the number of plant species present but also the spatial turnover of plant species among neighbouring areas is thus an important aspect in shaping the diversity of butterflies and grasshoppers in this subalpine habitat, possibly reflecting the considerable topographical heterogeneity in the areas studied. This outcome is in contrast to the results of Kessler et al. (2009), who compared 
species richness and $\beta$ diversity of plants and animals in Indonesia and found that $\beta$ diversity of one taxon had very limited indicator potential for species richness of other taxa. The differing results could be explained by the fact that Kessler et al. (2009) included different habitat types, and that some taxa showed divergent preference for specific habitats, while our study only included alpine grasslands. Nevertheless, the community similarity approach, which not only incorporates the abundances of single species but also provides information on the species identity, yielded strong congruencies between plants and invertebrates. This agrees with previous studies on surrogate indicators that found measures based upon community similarity to be more effective than those based on species richness (Bilton et al. 2006; Lovell et al. 2007; Su et al. 2004).

As the whole of biodiversity cannot be assessed, specific taxa are often used as surrogates for other taxa to reduce the time and cost of monitoring in conservation planning. The effort can be reduced even further if a subset of species from one taxon, rather than recording all species, is used. This approach is already utilized in agri-environment schemes in Switzerland and Germany, where result-oriented payments to the farmers and thus biodiversity conservation of agricultural areas are based on a list of plant indicator species (Oppermann and Gujer 2003). Our results indicate that the plant 'quality species' represent well species richness and community similarity of butterflies and grasshoppers. These findings partly contradict results from Vellend et al. (2008) who found that the strength of correlations for species richness and composition are reduced if only a subset of species is used; on the other hand, they argue that the use of a subset can even maximize statistical power, and that little information is lost by eliminating a small proportion of rare species (e.g. below $10 \%$ ). In any case, the success of a subset relative to all species will highly depend on how the species are selected; whilst the subsets used by Vellend et al. (2008) were obtained by removing species randomly, the so-called quality species used here were selected specifically for their conservation value.

In summary, our investigation of subalpine Swiss summer pastures has shown strong overall correspondence between vascular plants and two insect taxa, butterflies and grasshoppers, especially when community diversity measures are used rather than simple species richness. We therefore recommend the use of community similarity data in studies evaluating surrogacy, as this measure takes species identity as well as species abundance into account, just as do standard diversity indices. Although our correlations do not reach the value of 0.75 recommended by Lovell et al. (2007) as a criterion for accepting vascular plants as a suitable surrogate for other taxa, given the consistently strong correlations at the community level, we are confident that vascular plants represent an acceptable surrogate for butterflies and grasshoppers (though caution is required when the species pool is small). This in turn implies that conservation measures aimed primarily at protecting the plant diversity of subalpine grasslands will also benefit butterflies and grasshoppers, at least at the local scale at which management decisions are usually made. We expect a similar profit for other invertebrate taxa such as bumblebees or syrphid flies that show strong interactions with plants. Nevertheless, animal groups not directly related to plants are likely to show poor congruence. Therefore, Finch and Löffler (2010) recommended the use of one group of invertebrates in addition to plants as indicator for conservation planning in alpine areas. Given the lack of studies in these areas, more effort should be dedicated to investigate surrogacy, especially for invertebrate groups not directly related to specific plant taxa. As the results of this study are based on 1 year survey data, further research including multiyear analyses would also be needed to confirm the pattern detected. Furthermore, we conclude that recording a subset of vascular plants (the 'quality' species) can substantially increase the efficiency of assessments without reducing their predictive value as surrogates 
for other taxa. Our results suggest that the Swiss 'quality species' are well selected to represent insect species richness and community similarity. They, therefore, are well suited for assessing result-oriented policy.

Acknowledgments We thank Anna Stäubli and Nina Richner for help during the fieldwork. Thank you also to the landowners that permitted access to the field sites. The study is affiliated to the AlpFUTUR project (www.alpfutur.ch) and was partly funded by the Swiss Federal Office for the Environment (FOEN), Armasuisse, Kanton Graubünden, Ricola, and Sophie und Karl Binding Stiftung. We thank two anonymous reviewers for their constructive comments.

\section{References}

BAFU \& BLW (2008) Umweltziele Landwirtschaft. Hergeleitet aus bestehenden rechtlichen Grundlagen. Swiss Federal Office for Environment, Bern

Balmer O, Erhardt A (2000) Consequences of succession on extensively grazed grasslands for Central European butterfly communities: rethinking conservation practices. Conserv Biol 14(3):746-757

Bätzing W (2003) Die Alpen—Geschichte und Zukunft einer europäischen Kulturlandschaft. C.H. Beck, München

Baur B, Baur H, Roesti C, Roesti D (2006) Die Heuschrecken der Schweiz. Haupt, Bern

Baur P, Müller P, Herzog F (2007) Alpweiden im Wandel. Agrarforschung 14(6):254-259

Billeter R, Liira J, Bailey D, Bugter R, Arens P, Augenstein I, Aviron S, Baudry J, Bukacek R, Burel F, Cerny M, De Blust G, De Cock R, Diekötter T, Dietz H, Dirksen J, Dormann C, Durka W, Frenzel M, Hamersky R, Hendrickx F, Herzog F, Klotz S, Koolstra B, Lausch A, Le Coeur D, Maelfait JP, Opdam P, Roubalova M, Schermann A, Schermann N, Schmidt T, Schweiger O, Smulders MJM, Speelmans M, Simova P, Verboom J, van Wingerden WKRE, Zobel M, Edwards PJ (2008) Indicators for biodiversity in agricultural landscapes: a pan-European study. J Appl Ecol 45:141-150

Bilton DT, McAbendroth L, Bedford A, Ramsay PM (2006) How wide to cast the net? Cross-taxon congruence of species richness, community similarity and indicator taxa in ponds. Freshwater Biol 51:578-590

BLW (1998) Verordnung über die Direktzahlungen an die Landwirtschaft (Direktzahlungsverordnung, DZV). SR 910.13. Swiss Federal Office for Agriculture, Bern

BLW (2001) Verordnung über die regionale Förderung der Qualität und der Vernetzung von ökologischen Ausgleichsflächen in der Landwirtschaft (Öko-Qualitätsverordnung, ÖQV). SR 910.14. Swiss Federal Office for Agriculture, Bern

BLW (2007) Verordnung über Sömmerungsbeiträge (Sömmerungsbeitrasverordnung, SöBV). SR 910.133. Swiss Federal Office for Agriculture, Bern

BLW (2011) Agrarbericht 2011. Swiss Federal Office for Agriculture, Bern

Braun-Blanquet J (1964) Pflanzensoziologie. Grundzüge der Vegetationskunde. Springer, Wien

Bühler-Cortesi T (2009) Schmetterlinge-Tagfalter der Schweiz. Haupt, Bern

Caro TM, O'Doherty G (1999) On the use of surrogate species in conservation biology. Conserv Biol 13:805-814

Chiarucci A, D'Auria F, De Dominicis V, Laganà A, Perini C, Salerni E (2005) Using vascular plants as surrogate taxon to maximize fungal species richness in reserve design. Conserv Biol 19(5):1644-1652

Chiarucci A, D'Auria F, Bonini I (2007) Is vascular plant species diversity a predictor of bryophyte species diversity in Mediterranean forests? Biodivers Conserv 16:525-545

Dale MRT, Fortin M (2009) Spatial autocorrelation and statistical tests: some solutions. J Agr Biol Envir St 14:188-206

Detzel P (1998) Die Heuschrecken Baden-Württembergs. Verlag Eugen Ulmer, Stuttgart

Duelli P, Obrist MK (1998) In search of the best correlates for local organismal biodiversity in cultivated areas. Biodivers Conserv 7:297-309

Fattorini S (2010) Biotope prioritisation in the Central Apennines (Italy): species rarity and cross-taxon congruence. Biodivers Conserv 19:3413-3429

Favreau JM, Drew CA, Hess GR, Rubino MJ, Koch FH, Eschelbach KA (2006) Recommendations for assessing the effectiveness of surrogate species approaches. Biodivers Conserv 15:3949-3969

Finch O, Löffler J (2010) Indicators of species richness at the local scale in an alpine region: a comparative approach between plant and invertebrate taxa. Biodivers Conserv 19:1341-1352

Gioria M, Bacaro G, Feehan J (2011) Evaluating and interpreting cross-taxon congruence: potential pitfalls and solutions. Acta Oecol 37:187-194 
Heino J, Tolonen KT, Kotanen J, Paasivirta L (2009) Indicator groups and congruence of assemblage similarity, species richness and environmental relationships in littoral macroinvertebrates. Biodivers Conserv 18:3085-3098

Howard PC, Viskanic P, Davenport TRB, Kigenyi FW, Baltzer M, Dickinson CJ, Lwanga JS, Matthews RA, Balmford A (1998) Complementarity and the use of indicator groups for reserve selection in Uganda. Nature 394:472-475

Jackson DA (1995) PROTEST: a PROcrustean randomization TEST of community environment concordance. Écoscience 2:297-303

Kati V, Devillers P, Dufrêne M, Legakis A, Vokou D, Lebrun P (2004) Testing the value of six taxonomic groups as biodiversity indicators at a local scale. Conserv Biol 18:667-675

Kessler M, Abrahamczyk S, Bos M, Buchori D, Putra DD, Gradstein SR, Höhn P, Kluge J, Orend F, Pitopang R, Saleh S, Schulze CH, Sporn SG, Steffan-Dewenter I, Tjitrosoedirdjo SS, Tscharntke T (2009) Alpha and beta diversity of plants and animals along a tropical land-use gradient. Ecol Appl 19:2142-2156

Kim S (2011) ppcor: partial and semi-partial (Part) correlation. R package version 1.0, http://CRAN.Rproject.org/package=ppcor. Accessed 16 Nov 2012

Kleijn D, Sutherland WJ (2003) How effective are European agri-environment schemes in conserving and promoting biodiversity? J Appl Ecol 40:947-969

Klimek S, Kemmermann ARG, Steinmann H, Freese J, Isselstein J (2008) Rewarding farmers for delivering vascular plant diversity in managed grasslands: a transdisciplinary case-study approach. Biol Conserv 141:2888-2897

Lande R (1996) Statistics and partitioning of species diversity, and similarity among multiple communities. Oikos 76:5-13

Lauber K, Wagner G (2001) Flora Helvetica. Haupt, Bern

Lovell S, Hamer M, Slotow R, Herbert D (2007) Assessment of congruency across invertebrate taxa and taxonomic levels to identify potential surrogates. Biol Conserv 139:113-125

MacDonald D, Crabtree JR, Wiesinger G, Dax T, Stamou N, Fleury P, Gutierrez-Lazpita J, Gibon A (2000) Agricultural abandonment in mountain areas of Europe: environmental consequences and policy response. J Environ Manage 59:47-69

Mack G, Flury C (2008) Wirkung der Sömmerungsbeiträge. Agrarforschung 15(10):500-505

Mack G, Walter T, Flury C (2008) Entwicklung der Alpung in der Schweiz: Ökonomische und ökologische Auswirkungen. In: Yearbook of socioeconomics in Agriculture 2008 p 259-300

Mandelik Y, Dayan T, Chikatunov V, Kravchenko V (2012) The relative performance of taxonomic versus environmental indicators for local biodiversity assessment: a comparative study. Ecol Indic 15:171-180

Marini L, Scotton M, Klimek S, Isselstein J, Pecile A (2007) Effects of local factors on plant species richness and composition of Alpine meadows. Agr Ecosyst Environ 119:281-288

Marini L, Fontana P, Klimek S, Battisti A, Gaston KJ (2009) Impact of farm size and topography on plant and insect diversity of managed grasslands in the Alps. Biol Conserv 142:394-403

McGeoch MA (1998) The selection, testing and application of terrestrial insects as bioindicators. Biol Rev 73:181-201

Moran MD (2003) Arguments for rejecting the sequential Bonferroni in ecological studies. Oikos 100:403-405

Murdoch WW, Evans FC, Peterson CH (1972) Diversity and pattern in plants and insects. Ecology 53(5):819-829

Niemelä J, Baur B (1998) Threatened species in a vanishing habitat: plants and invertebrates in calcareous grasslands in the Swiss Jura mountains. Biodivers Conserv 7:1407-1416

Nipperess DA, Beattie AJ, Faith DP, Ginn SG, Kitching RL, Reid CAM, Russell T, Hughes L (2012) Plant phylogeny as a surrogate for turnover in beetle assemblages. Biodivers Conserv 21:323-342

Noss RF (1990) Indicators for monitoring biodiversity: a hierarchical approach. Conserv Biol 4(4):355-364

Oertli S, Müller A, Steiner D, Breitenstein A, Dorn S (2005) Cross-taxon congruence of species diversity and community similarity among three insect taxa in a mosaic landscape. Biol Conserv 126:195-205

Oksanen J, Guillaume Blanchet F, Kindt R, Legendre P, Minchin PR, O’Hara RB, Simpson GL, Solymos P, Stevens MHH, Wagner H (2012) vegan: Community Ecology Package. R package version 2.0-4, http://CRAN.R-project.org/package=vegan. Accessed 16 Nov 2012

Oppermann R, Gujer HU (2003) Artenreiches Grünland: Bewerten und fördern-MEKA und ÖQV in der Praxis. Ulmer, Stuttgart

Panzer R, Schwartz MW (1998) Effectiveness of a vegetation-based approach to insect conservation. Conserv Biol 12:693-702

Pearman PB, Weber D (2007) Common species determine richness patterns in biodiversity indicator taxa. Biol Conserv 138:109-119 
Peres-Neto PR, Jackson DA (2001) How well do multivariate data sets match? The advantages of a Procrustean superimposition approach over the Mantel test. Oecologia 129:169-178

Pharo EJ, Beattie AJ, Binns D (1999) Vascular plant diversity as a surrogate for bryophyte and lychen diversity. Conserv Biol 13:282-292

Prendergast JR, Quinn RM, Lawton JH, Eversham BC, Gibbons DW (1993) Rare species, the coincidence of diversity hotspots and conservation strategies. Nature 365:335-337

Reinhard M, Bächlin R, Graeter P, Lehner P, Spicher A (1962) Geologischer Atlas der Schweiz, 9th edn. Kümmerly and Frey, Bern

R Core Team (2012) R: A language and environment for statistical computing. R Foundation for Statistical Computing, Vienna, Austria. ISBN 3-900051-07-0, http://www.R-project.org/. Accessed 16 Nov 2012

Samways MJ, Hamer M, Veldtman R (2012) Development and future of insect conservation in South Africa. In: New TR (ed) Insect conservation: past, present and prospects. Springer, Berlin, pp 245-278

Santi E, Maccherini S, Rocchini D, Bonini I, Brunialti G, Favilli L, Perini C, Pezzo F, Piazzini S, Rota E, Salerni E, Chiarucci A (2010) Simple to sample: vascular plants as surrogate group in a nature reserve. J Nat Conserv 18:2-11

Sauberer N, Zulka KP, Abensperg-Traun M, Berg H, Bieringer G, Milasowszky N, Moser D, Plutzar C, Pollheimer M, Storch C, Tröstl R, Zechmeister H, Grabherr G (2004) Surrogate taxa for biodiversity in agricultural landscapes of eastern Austria. Biol Conserv 117:181-190

Schweizerische Meteorologische Anstalt (2008) Annalen der Schweizerischen Meteorologische Anstalt, vol 145. Bundesamt für Meteorologie und Klimatologie, Zürich

Su JC, Debinski DM, Jakubauskas ME, Kindscher K (2004) Beyond species richness: community similarity as a measure of cross-taxon congruence for coarse-filter conservation. Conserv Biol 18(1):167-173

Szövényi G (2002) Qualification of grassland habitats based on their Orthoptera assemblages in the Köszeg Mountains (W-Hungary). Entomol Exp Appl 104:159-163

Tasser E, Tappeiner U (2002) Impact of land use changes on mountain vegetation. Appl Veg Sci 5:173-184

Tudor O, Dennis RLH, Greatorex-Davies JN, Sparks TH (2004) Flower preferences of woodland butterflies in the UK: nectaring specialists are species of conservation concern. Biol Conserv 119:397-403

Vellend M, Lilley PL, Starzomski BM (2008) Using subsets of species in biodiversity surveys. J Appl Ecol 45:161-169

Vera P, Sasa M, Encabo SI, Barba E, Belda EJ, Monrós JS (2011) Land use and biodiversity congruences at local scale: applications to conservation strategies. Biodivers Conserv 20:1287-1317

Vessby K, Söderström B, Glimskär A, Svensson B (2002) Species-richness correlations of six different taxa in Swedish seminatural grasslands. Conserv Biol 16(2):430-439

Weaver JC (1995) Indicator species and scale of observation. Conserv Biol 9:939-942

Wittig B, Kemmermann ARG, Zacharias D (2006) An indicator species approach for result-oriented subsidies of ecological services in grasslands: a study in Northwestern Germany. Biol Conserv 133:186-197

Wolters V, Bengtsson J, Zaitsev AS (2006) Relationship among the species richness of different taxa. Ecology 87(8):1886-1895

Zoller H, Bischof N (1980) Stufen der Kulturintensität und ihr Einfluss auf Artenzahl und Artengefüge der Vegetation. Phytocoenologia 7:35-51 